\title{
Recent and potential future developments in judicial protection in the European Area of Freedom, Security and Justice
}

\author{
Johanna Engström
}

Published online: 5 March 2009

(C) ERA 2009

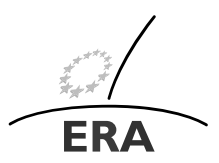

EUROPÄISCHE RECHTSAKADEMIE ACADEMY OF EUROPEAN LAW ACADEMIE DE DROIT EUROPEEN ACCADEMIA DI DIRITTO EUROPEO TRIER - TREVES - TREVIRI

\section{Introduction}

This issue of ERA Forum focuses on the Area of Freedom, Security and Justice and more particularly on matters relating to Asylum and Immigration (Title IV or the EC Treaty) and Judicial Cooperation in Criminal Matters (Title VI of the EU Treaty). While these subject-matters initially co-habited in the third pillar, they appear, after the Amsterdam Treaty, in different pillars and are consequently governed by different institutional and regulatory frameworks. Notwithstanding being governed by different frameworks, the two subject-matters still share common features that create a special 'bond' between them. One such feature is the particular need for protection of rights and fundamental rights because of the specific risk for individual liberties and the right to self-determination in those areas where breaches tend to have serious and far-reaching negative effects on the individual. In a system governed by the rule of law such protection is ultimately ensured by the judiciary and this is also the case in the European Union.

This editorial will discuss some topical aspects of the judicial protection of individuals in the matters that are of focus in this edition and it will analyse to what extent these adequately address the need for judicial protection in the relevant fields. It will also address some remaining challenges that need to be met to ensure an adequate judicial protection in matters relating to Asylum and Immigration and Judicial Cooperation in Criminal Matters. It will be argued that the Lisbon Treaty brings about

\section{J. Engström $(\bowtie)$}

Section III-Public and Criminal Law, Academy of European Law, Metzer Allee 4, 54295 Trier,

Germany

e-mail: jengstroem@era.int 
crucial and needed changes to the judicial protection in Title IV of the EC Treaty and Title VI of the EU Treaty (Sect. 2); changes which are crucial in order to ensure the effectiveness of for example the newly introduced urgent preliminary reference proceedings (Sect. 3). It will be argued that the response to the increased need for judicial protection of individuals in the areas mentioned in the near future lie rather with the legislator than with the Court of Justice, which is at present quite effectively using the means at its disposal to ensure judicial protection in the areas concerned. ${ }^{1}$

\section{The Lisbon Treaty - the answer to incomplete judicial protection in the area of criminal justice and asylum and immigration?}

The question of judicial protection has been of some concern in both the area of asylum and immigration and especially in matters of police and judicial cooperation in criminal matters. It has already been stressed that in those areas individuals are more susceptible to suffer detriment by an insufficient or ineffective judicial protection, especially as they might be deprived of or suffer limitations to their personal freedom. For this reason the judicial remedies offered in the EU system must ensure that the legality of measures can be effectively reviewed, that individuals will benefit from a complete system of remedies and that the delays are reasonable.

In the area of police and judicial cooperation in criminal matters, the concern has been both the limited judicial remedies that are currently available before the EU courts, such as the optional nature of the preliminary reference proceedings, ${ }^{2}$ the watered-down possibility for infringement proceedings (Article 35 (7) EU) and the limits to the possibility to bring annulment proceedings (Article 35 (6) EU). The effectiveness of the preliminary reference procedure has also been questioned in circumstances where a person is detained and must stay in custody for 19 months ${ }^{3}$ before the Court of Justice rules on the matter.

As concerns judicial protection in the area of asylum and immigration, the transfer of the matter to the first pillar has indeed improved judicial protection in the area. ${ }^{4}$ As the 'general' remedies apply, it is for instance possible for the European Parliament to initiate annulment proceedings and the Parliament has in this context made use of its right of action to ensure institutional balance and that fundamental and individual rights are protected. This was for example the case in C-540/03, where the Parliament, albeit unsuccessfully, challenged the Family Reunification Directive on a number of

\footnotetext{
${ }^{1}$ To this extent, see also the Court's ruling in Joined Cases C-402/05 P and C-415/05 P Kadi \& Al Barakaat v. Council, judgment 3 September 2008, which shows the Court's determination to ensure an effective judicial protection of individuals.

${ }^{2}$ In March 2008, 17 member states had made declarations pertaining to the Court Justice's competence under Article 35 (in chronological order: Germany, Austria, Belgium, Spain, Finland, France Greece, Hungary, Italy, Latvia, Lithuania, Luxembourg, Netherlands, Portugal, Czech Republic, Slovenia, Sweden). Of these member states it is only Spain that has limited the right to refer a preliminary reference to courts against whose ruling there is no judicial remedy.

${ }^{3}$ During 2007 it took the Court of Justice on average 19.3 months to deliver a preliminary ruling.

${ }^{4}$ This also applies to Judicial Cooperation in Civil matters, which was equally transferred to the first pillar by the Amsterdam Treaty and which also is governed by Article 68 TEC.
} 
grounds. ${ }^{5}$ Recently the Parliament successfully sought the annulment of the Directive on minimum standards on procedures for granting refugee status in Case C-133/06. Although the Court has compulsory jurisdiction over matters dealt with in Title IV of the EC Treaty, and the general 1st pillar remedies apply as was just alluded to, Article 68 EC states that Article 234 EC shall apply only where a question of interpretation or validity of Community law acts is raised before a court of a tribunal against whose judgments there is no judicial remedy. This limitation of course results in a risk that EU asylum law might lose in effectiveness and that individuals might be deprived of rights and safeguards as a result of the incorrect interpretation of EU law by lower instances. The last instances indeed have an obligation to refer, but in practice one can doubt whether cases concerning asylum and immigration will be pursued to last instance, considering the economic, social, psychological and practical difficulties for individuals to appeal their case.

Some of the solutions to the mentioned problems of judicial protection are to be found in the Lisbon Treaty. ${ }^{6}$ The Court would be competent to answer preliminary rulings also from lower courts in the area of asylum and immigration (Article 267 TFEU). This will with time ensure a greater coherence in the interpretation of European Union law, and hopefully a more effective protection of rights, provided that the Court sets a high minimum standard for protection. Also certain of the problems listed above that concern the judicial protection in the area of police and judicial cooperation in criminal matters would be addressed if the Lisbon Treaty enters into force, as the third pillar would be 'communitarised'. Firstly, the jurisdiction of the Court of Justice to hear preliminary references would become compulsory and not optional and it would be possible for all national courts and tribunals in the member states $^{7}$ to refer a question (Article 267 TFEU). This would hopefully result in more case-law and greater consistency in the interpretation of instruments such as the European Arrest Warrant, where national courts still might need guidance, something which in this edition is illustrated by the contribution by Luis Pereira, which provides an analysis of The Portuguese Implementing Measures in Respect of the EAW as well as the Portuguese courts' interpretation of these measures. Secondly, with the entry into force of the Treaty of Lisbon, infringement proceedings would be available for breaches of obligations in the area of police and judicial cooperation in criminal matters committed by member states (Articles 258-260 TFEU) under the 'usual' procedure. Thirdly, the annulment procedure currently available for third pillar legal acts (Article 35 (6) EU) would equally leave place for application of the regular annulment procedure (now Article 230 EC) and also acts by Eurojust and Europol would be open to review. Hereby the European Parliament and individuals (at least in theory) will be able to challenge acts adopted in the area of police and judicial cooperation in criminal matters. In view of the constant evolution of the EU's action in the area, where the article of Paul Gallagher on the Future developments in judicial cooperation in criminal matters provides insight into the preparation of the new multi-annual framework for the Area of Freedom, Security and Justice, the quest for

\footnotetext{
${ }^{5}$ Case C-540/03 European Parliament v. the Council of the European Union [2006] ECR I-5769.

${ }^{6} \mathrm{New}$ problems might however arise, which will be addressed in Sect. 3 of this editorial.

${ }^{7}$ The possibility for certain countries to opt out should of course also be taken into account.
} 
an effective judicial protection of individuals and their rights within the EU criminal justice system appears all the more pressing.

Besides bringing the different matters that make up the Area of Freedom, Security and Justice into the same framework, and henceforth erasing the complications and inconsistencies arising from the pillar structure, the Lisbon Treaty would ensure an improved judicial protection in the areas of asylum and immigration and police and judicial cooperation in criminal matters. While one should of course not be indifferent to the reason for the current regulation of judicial remedies in the third pillar, i.e. Member States' sensitivity to EU involvement in matters of criminal justice, one can still question the appropriateness of limiting - at the expense of individuals - the judicial control and effective application of acts which have actually been adopted unanimously. In view of the ever-expanding horizon of police and judicial cooperation in criminal matters, where EU impact on new topics is constantly under discussion-illustrative examples from this edition of ERA Forum are found in the article of Franck Dumortier on Using biometrics and RFIDS chips in the European Area of Liberty, Security and Justice-a question of balance or a question of dignity and the article by Christine Morgenstern on Pre-trial/remand detention in Europe-a complete system of remedies and an increased judicial protection in this field, as brought about by the Lisbon Treaty, are most welcome. To sum up, the shortcomings addressed in this section would in large be remedied by the Lisbon Treaty which makes an important contribution to increasing judicial control and protection in the areas of police and judicial cooperation in criminal matters and asylum and immigration. ${ }^{8}$

One problem that the Lisbon Treaty does not resolve, however, is the delays in obtaining a preliminary ruling in the Area of Freedom, Security and Justice, delays that in practice can result in rendering rights virtually impossible to exercise. The recent introduction of the urgent preliminary reference proceedings is intended to circumvent the problem of delays in the area immigration and asylum and judicial cooperation in criminal (and civil) matters.

\section{The urgent preliminary reference procedure-a real improvement to the effectiveness of judicial protection in matters of asylum, immigrations and criminal justice?}

At first regard, the urgent preliminary reference procedure ${ }^{9}$ appears as a big step on the right way to ensure an effective judicial protection for individuals in the EU. The procedure, which entered into force on 1 March 2008 allows for a significant acceleration of the preliminary reference procedure. In the cases where the Court thus far

\footnotetext{
${ }^{8}$ The Treaty of Lisbon also brings other changes to the judicial system, and these are in this issue discussed by Bernard Chevalier in Les nouveaux développements de la procédure préjudicielle dans le domaine de l'espace judiciaire européen: la procédure préjudicielle d'urgence et les réformes principales prévues par le traité de Lisbonne.

${ }^{9}$ The procedure is provided for in Article 23 a of the Statute of the Court of Justice and Article $104 \mathrm{~b}$ of its Rules of Procedure.
} 
has used the procedure the average time for obtaining a ruling has been 62 days, i.e. ca. two months, to be compared with the usual 19 months. ${ }^{10}$ The urgent preliminary reference proceeding is available when a reference for a preliminary ruling raises one or more questions in the area covered by Title VI of the European Union Treaty or Title IV of Part three of the EC Treaty, i.e. in relation to judicial cooperation in criminal matters, asylum and immigration or judicial cooperation in civil matters. The details of the procedure are discussed in the article of Bernard Chevalier, Les nouveaux développements de la procédure préjudicielle dans le domaine de l'espace judiciaire européen: la procédure préjudicielle d'urgence et les réformes principales prévues par le traité de Lisbonne. The procedure is to be employed at the request of the national court or tribunal or, exceptionally, on the Court's own motion. The national court or tribunal must in its request set out the matters of facts and law which establish the urgency and justify the application of this exceptional procedure. It shall also, in so far as possible, indicate the answer it proposes to the questions referred. ${ }^{11}$ The decision to apply the urgent preliminary reference procedure is made by one of the Court's Chambers after hearing the Advocate General, ${ }^{12}$ and this Chamber also handles the reference if the urgent procedure is approved. The acceleration of the procedure is partly achieved by limiting the right for interested persons (whose regular right to intervene is regulated by Article 23 of the Statute) to submit written observations, a step that usually takes considerable time due to the need to translate those observations. ${ }^{13}$ The interests of the member states, other than the one from which the reference is made, is safeguarded through a right to intervene and have their points of view taken into account orally at the hearing.

On the basis of this limited material for analysis, one can conclude that the urgent preliminary reference has accelerated the procedure considerably, with an average time of 2 months for a ruling, instead of 19 months. The Court of Justice has responded excellently in limiting the delays to the minimum when it considers that there is urgency. ${ }^{14}$ Can one, however, on this basis conclude that the urgent preliminary reference proceeding in general constitutes an important and big step towards increased judicial protection under European Union law, and especially in matters where individuals are deprived of their liberty or risk expulsion in matters of asylum and immigration or judicial cooperation in criminal matters?

There are several considerations that cast doubt on whether the urgent preliminary reference really makes a major contribution to effective judicial protection for

\footnotetext{
${ }^{10}$ See C-195/08 PPU Rinau, judgment of 11 July 2008 (58 days), C-296/08 PPU Esteban Goicoecha (40 days) judgment of 12 August 2008, C-388/08 PPU Leymann (87 days), judgment of 1 December 2008.

${ }^{11}$ See Rules of Procedure of the Court of Justice, Article 104 (b).

${ }^{12}$ The Advocate General's opinion is not made public and there is at present a debate going on whether this opinion should be published, which might, indeed, prolong the procedure.

${ }^{13}$ Article 23 a of the Statute and Article 104 (b) para 2, Rules of Procedure of the Court of Justice.

${ }^{14}$ It is still uncertain exactly under what circumstances the court will really consider there to be urgency and what factors it will consider important. Some guidelines are given in the Supplement to the Court's information note on references from national courts for a preliminary ruling following the implementation of the urgent preliminary ruling procedure applicable to references concerning the area of freedom, security and justice p. 7, http://curia.europa.eu/en/instit/txtdocfr/txtsenvigueur/noteppu.pdf, but this will be further developed in case-law.
} 
individuals in need of an urgent answer to a preliminary ruling. First, one could inquire whether it is justified to limit the availability of urgent preliminary references to matters arising in relation to Title VI of the European Union Treaty or Title IV of Part three of the EC Treaty, i.e. in relation to judicial cooperation in criminal matters, asylum and immigration or judicial cooperation in civil matters. We have recently experienced that acts that concern criminal law can also be adopted under Community law, i.e. as first pillar instruments ${ }^{15}$ and this increases the possibility of national courts needing an urgent answer on how to interpret EU law when a person is in custody even outside the scope of the aforementioned areas. There can also be situations where third country nationals risk expulsion or are detained and the national court needs an interpretation of a legal act adopted outside Title IV of the EC Treaty-for example on the basis of the rules on free movement for EU citizens such as Directive 2004/38/EC. ${ }^{16}$ This problematic is illustrated by the case C-127/08 Metock where the Directive's application arose in a case concerning third country nationals that risked, and in some cases actually were expelled during the proceedings. ${ }^{17}$ While it is true that the preliminary reference in Metock was still handled expediently (exactly in 2 months), as this was one of the rare occasions when the Court decided to use the accelerated procedure ${ }^{18}$ the case exemplifies the difficulty in letting the judicial protection afforded to an individual depend solely on the legal basis of an act applied to him/her, instead of focusing on the particular circumstances in the case and the situation of the individual. In this issue, Anthony Collins discusses inter alia the Metock case, the limits of the urgent preliminary reference procedure and further recent substantive and procedural developments in the article Recent developments in asylum and immigration law before the Court of Justice in the area of asylum and immigration.

A second consideration that puts into doubt the importance of urgent preliminary reference proceedings for increasing judicial protection is the restrictions to the judicial bodies that can actually refer a matter in relation to asylum and immigration matters, Article $68 \mathrm{EC}$. The need to urgently have a preliminary ruling will mostly arise when the case is heard before the first administrative or judicial instance. As only last instances are allowed to refer preliminary references in asylum and immigration matters, the case must be brought to the last instance in order for an 'urgent reference procedure' to be possible. With the risk of sounding cynical, it might not be easy to convince the Court of Justice that there is urgency after months, or rather years, of appeals. But, maybe more importantly, individuals will rarely have the means to bring their case to the last resort of the judicial machinery and it is likely that in

\footnotetext{
${ }^{15}$ See Case C-176/03 Commission v Council (Environmental Crimes) [2005] ECR I-7879, Case C-440/05 Commission v Council (Ship source pollution) [2007] ECR I-9097.

${ }^{16}$ Directive 2004/38/EC of the European Parliament and of the Council of 29 April 2004 on the right of citizens of the Union and their family members to move and reside freely within the territory of the Member States amending Regulation (EEC) No. 1612/68 and repealing Directives 64/221/EEC, 68/360/EEC, 72/194/EEC, 73/148/EEC, 75/34/EEC, 75/35/EEC, 90/364/EEC, 90/365/EEC and 93/96/EEC, OJ L 158, 30.4.2004, pp. 77-123.

${ }^{17}$ Case C-127/08 Metock and others, judgment of 25 July 2008.

${ }^{18}$ The accelerated procedure is provided for in Article 104 a of the Rules of Procedure.
} 
many cases the individual will already have been deported, left the country voluntarily or given up before the possibility to obtain an urgent preliminary reference is even open to him. ${ }^{19}$ Hence, the practical use of the urgent preliminary reference proceedings in matters of asylum and immigration will most certainly be limited until all national tribunals and courts have the competence to refer preliminary rulings to the Court of Justice. ${ }^{20}$ In matters relating to asylum and immigration doubts persist as to whether the procedure is anything more than a minor step on a road where a rather long distance yet remains to be covered in order to ensure effective protection of third country nationals. While these shortcomings do not put the merits of the urgent preliminary reference procedure as such in doubt, they do highlight the difficulties of finding a clear-cut formula which singles out the cases that potentially might require an urgent preliminary ruling to make judicial protection as effective as possible.

To what extent would the Lisbon Treaty affect the urgent preliminary reference procedure and the aforementioned shortcomings? As all courts and tribunals of the member states ${ }^{21}$ would have the possibility to ask for a preliminary reference, also in police and judicial cooperation in criminal matters and asylum and immigration, it would ensure that in all situations where someone is in custody and needs a preliminary reference urgently, this person can benefit from the procedure, as long as the reference pertains to a legal instrument relating to these areas. This might, however, result in more frequent requests for urgent preliminary rulings and could consequently lead to a slow-down of the procedure and/or a prolongation of 'ordinary' preliminary reference proceedings. Secondly, the Lisbon Treaty does not directly affect the availability of the urgent preliminary procedure so that it would be available in other circumstances where a person in custody, deprived of his liberty or risking expulsion (as in Metock) might need a preliminary ruling urgently; the Lisbon Treaty does in itself not bring about any change to Article 104 (b) para 1 in the Rules of Procedure, which limits the availability to the area of asylum and immigration and judicial cooperation in civil and police and criminal matters. In such circumstances, use of the accelerated procedure would be the only option for obtaining effective judicial protection, still however with the risk of rescinding the exceptional nature of that procedure. It is interesting to note that the Lisbon Treaty (Article 267 (4) TFEU), provides that 'when a question arises with regard to a person in custody, the Court of Justice shall act with the minimum delay'. It remains to be seen whether this paragraph will encourage any legislative change as to the circumstances and subject-matters in which an urgent preliminary reference will be available and whether a person who is in custody waiting for a preliminary reference in relation to an 'ordinary' first pillar measure also will be able to benefit from increased judicial protection.

\footnotetext{
${ }^{19}$ It is not surprising that there has not been any request for an urgent preliminary reference proceedings in matters of Title IV of the EC Treaty.

${ }^{20}$ This problem would be addressed with the entry into force of the Treaty of Lisbon; in asylum and immigration matters all national courts would be competent to refer preliminary rulings, and hence also ask for an urgent preliminary ruling.

${ }^{21}$ Except for the limitations which the countries that have the right to opt-out from judicial cooperation in criminal matters (Denmark, Ireland and the United Kingdom) might have.
} 


\section{Conclusion}

This editorial has addressed the question of judicial protection in the areas which are in focus in this issue, i.e. asylum and immigration and police and judicial cooperation in criminal matters. Several of the shortcomings discussed would be addressed if the Lisbon Treaty enters into force. A recent improvement in judicial protection in the areas concerned is the urgent preliminary reference proceedings, but certain doubts as to its effectiveness for all situations where a person is deprived of his/her liberty have been raised, and it remains to be seen whether there is a need to reconsider the conditions under which such a reference can be sought. The observations made lead to the conclusion that the main challenge to ensure truly effective judicial protection in the recent future lies with the legislator and the member states who will need to make the necessary amendments to the Treaty and other relevant instruments. 